\title{
Pengaruh Ukuran Partikel Dan Suhu Terhadap Penyerapan Logam Tembaga (Cu) Dengan Arang Aktif Dari Kulit Pisang Kepok (Musa Paradisiaca Formatypica)
}

\author{
Donna Imelda ${ }^{1)}$, Amalia Khanza ${ }^{2)}$, dan Dita Wulandari ${ }^{3)}$ \\ Program Studi Teknik Kimia, Fakultas Teknologi Industri, Universitas Jayabaya \\ Jl. Raya Bogor KM 28,8 Cimanggis-Jakarta Timur \\ Corresponding author: deimelda18@gmail.com
}

\begin{abstract}
Heavy metal in waters is dangerous for aquatic ecosystems. The one is copper $(\mathrm{Cu})$, that kill fish at concentration 2.5-3.0ppm. This study aims to determine effect of temperature and particle size in absorption of $\mathrm{Cu}$ by biosorbent activated charcoal from kepok banana peel which it has pectin. Activated charcoal made at $250^{\circ} \mathrm{C}$ for 2 hours and activated by $3 \mathrm{M} \mathrm{HCl}$ for 7 hours. Dry activated charcoal tested according to SNI 06-3730-1995. Consentration Cu solution used: 20ppm, pH of Cu soluton: 3, contact time: 10 minutes. With the variables studied were particle size (Mesh: 10, 40, 80, 100 , and 200) and temperature $\left(20^{\circ} \mathrm{C}, 40^{\circ} \mathrm{C}, 60^{\circ} \mathrm{C}, 80^{\circ} \mathrm{C}\right.$ and $\left.100^{\circ} \mathrm{C}\right)$. After laboratory analysis and ANOVA statistical test, the results showed that variations in particle size and temperature affected the amount of $\mathrm{Cu}$ concentration absorbed by activated charcoal. More smaller particle size more greater surface area of activated charcoal more greater concentration of $\mathrm{Cu}$ absorbed. More greater the temperature more greater concentration of $\mathrm{Cu}$ absorbed by activated charcoal, but if it's too hot, pores of activated charcoal will be damaged. With water $8 \%$, sulfated ash 7\%, Iod number $2356 \mathrm{mg} / \mathrm{g}$, benzene number $51 \%$ and density $0.32 \mathrm{~g} / \mathrm{ml}$, all active charcoal tests meet criteria of SNI 06-37301995.
\end{abstract}

\begin{abstract}
Abstrak
Limbah logam dalam perairan berbahaya untuk ekosistem air. Salah satunya adalah logam tembaga $(\mathrm{Cu})$, yang dapat membunuh ikan-ikan pada konsentrasi 2.5-3.0 ppm. Penelitian ini bertujuan untuk mengetahui pengaruh suhu dan ukuran partikel terhadap penyerapan logam $\mathrm{Cu}$ oleh biosorben arang aktif dari kulit pisang kapok yang memiliki pektin. Arang aktif dibuat pada suhu $250{ }^{\circ} \mathrm{C}$ selama 2 jam. Diaktivasi dengan $\mathrm{HCl} 3 \mathrm{M}$ selama 7 jam. Kemudian dikeringkan, diuji mutu arangnya sesuai SNI 063730-1995. Proses penyerapan $\mathrm{Cu}$ dilakukan dengan kondisi konsentrasi larutan $\mathrm{Cu}: 20 \mathrm{ppm}, \mathrm{pH}$ larutan $\mathrm{Cu}$ : 3, waktu kontak dengan arang aktif: 10 menit. Dengan variabel yang diteliti yaitu ukuran partikel (Mesh: 10, 40, 80, 100, dan 200) dan suhu $\left(20^{\circ} \mathrm{C}, 40^{\circ} \mathrm{C}, 60^{\circ} \mathrm{C}, 80^{\circ} \mathrm{C}\right.$ dan $100^{\circ} \mathrm{C}$ ). Setelah dianalisa laboratorium dan analisa uji statistik menggunakan ANOVA, diperoleh hasil variasi ukuran partikel dan suhu berpengaruh pada besarnya konsentrasi $\mathrm{Cu}$ yang dijerap oleh arang aktif. Semakin kecil ukuran partikel semakin besar luas permukaan arang aktif semakin besar konsentrasi $\mathrm{Cu}$ yang terjerap. Semakin besar suhu semakin besar konsentrasi $\mathrm{Cu}$ yang terjerap, tetapi bila terlalu panas, pori-pori arang aktif akan rusak. Dengan kadar air $8 \%$, kadar abu $7 \%$, bilangan iod $2356 \mathrm{mg} / \mathrm{g}$, bilangan benzene $51 \%$ dan berat jenis $0.32 \mathrm{~g} / \mathrm{ml}$ seluruh uji mutu arang aktif memenuhui kriteria SNI 06-3730-1995.
\end{abstract}

Keywords: Biosorbent, Pectin, Particle Size, Copper Heavy Metal, Active Charcoal Quality 


\section{Pendahuluan}

Seiring dengan pertambahan jumlah penduduk dan industri, beban pencemaran yang disebabkan oleh pembuangan limbah industri dan domestik pun bertambah. Salah satunya pencemaran lingkungan air oleh logam berat. Keberadaan logam berat dalam air yang tidak dapat dilihat secara kasat mata dapat menjadi racun yang akan meracuni tubuh makhluk hidup. Sehingga, menjaga keberadaan air bersih sebagai salah satu sumber kehidupan menjadi sangatlah penting. Efek ion logam berat dalam air yang terakumulasi melalui rantai makanan dapat menjadi ancaman bagi hewan dan manusia.

Keberadaan logam berat dalam organisme hidup dapat menghambat aktivitas enzim, termasuk sistem antioksidan. Ion-ion logam berat bersifat toksik meskipun pada konsentrasi yang rendah (dalam ppm) dan umumnya sebagai polutan utama bagi lingkungan. Salah satu jenis logam berat itu adalah $\mathrm{Cu}$ (Tembaga). Dampak dari masuknya polutan $\mathrm{Cu}$ ke dalam tubuh dapat mengakibatkan kram perut, mual, muntah, diare, kerusakan ginjal, liver bahkan kematian. Dewasa ini, untuk mengurangi konsentrasi logam pemanfaatan bahan-bahan organik yang dijadikan sebagai bahan penyerap telah banyak dilakukan, bahan-bahan organik tersebut diubah menjadi arang hayati untuk mengadsorpsi logam berat sehingga dapat mengurangi pencemaran dan penyakit yang diakibatkan logam-logam berat tersebut.

Indonesia sebagai negara beriklim tropis yang memungkinkan tanahnya ditumbuhi berbagai jenis tanaman. Salah satu tanaman yang banyak tumbuh adalah tanaman pisang. Pemanfaatan tanaman pisang ini mulai dari buah, daun, bonggol, hingga kulit dari pisang dapat dilakukan. Kulit pisang dapat dimanfaatkan menjadi berbagai olahan daur ulang, salah satunya arang aktif yang memiliki kemampuan dalam mengikat ion logam berat. Kualitas mutu arang aktif diatur dalam SNI 06-3730-1995. Di Cilangkap Depok banyak pemanfaatan daging pisang kepok sebagai pakan unggas yang menghasilkan sisa kulit pisang kepok. Banyaknya pemanfaatan daging pisang kepok di daerah tersebut ikut menghasilkan limbah kulit pisang kepok. Warga sekitar belum tahu bahwa limbah kulit pisang kepok dapat didaur ulang menjadi arang aktif yang dapat dimanfaatkan untuk mengikat ion logam berat, sehingga warga hanya membuangnya. Limbah kulit pisang kepok yang dibuang dapat menyebabkan pencemaran air maupun tanah. Sehingga kami melakukan penelitian menggunakan bahan baku limbah kulit pisang kepok tersebut untuk dijadikan arang aktif. Penelitian ini bertujuan untuk mengetahui arang aktif yang dibuat dari kulit pisang kepok sesuai syarat mutu SNI 06-3730-1995 dan untuk mengetahui pengaruh dari ukuran partikel dan suhu dalam penyerapan tembaga $(\mathrm{Cu})$ dalam air dengan menggunakan biosorben kulit pisang kepok.

Penelitian sebelumnya tentang pemanfaatan limbah kulit pisang sebagai karbon aktif telah dilakukan oleh [1] dimana arang kulit pisang yang dihasilkan dapat digunakan untuk mengadsorpi Iod; [2] melakukan penelitian tentang adsorpsi timbal ( $\mathrm{Pb})$ dan zink ( $\mathrm{Zn})$ dari larutan dengan menggunakan arang hayati (biocharcoal) dari kulit pisang kepok berdasarkan variasi $\mathrm{pH}$; dan [3] tentang pengaruh aktivasi arang kulit pisang kepok sebagai adsorben besi (II) pada air tanah dihasilkan kondisi optimum untuk pembuatan arang aktif dari kulit pisang menggunakan $\mathrm{HCl} 3 \mathrm{M}$ dan proses penyerapan optimum terhadap ion besi (II) dalam air adalah dengan pengkondisian $\mathrm{pH} 3$ pada prosesnya. Waktu kontak optimum yang digunakan adalah selama 10 menit dengan jumlah arang aktif sebanyak 3 gram.. 


\section{Teori}

Ukuran partikel adalah karakteristik geometrik yang biasanya ditetapkan untuk bendabenda material dengan ukuran mulai dari nanometer hingga milimeter. Makin besar angka ukuran mesh screen, makin halus material dan makin luas ukuran partikel material. Suhu adalah besaran fisika yang menyatakan derajat panas suatu zat. naik turunnya tingkat adsorpsi di pengaruhi oleh temperatur. Pemanasan adsorben akan menyebabkan pori-pori adsorben terbuka sehingga daya serapnya meningkat. Tetapi pemanasan yang terlalu juga dapat membuat struktur adsorben rusak sehingga daya serapnya menurun.

Kulit pisang mengandung selulosa dan pektin yang cukup tinggi. Kulit pisang mengandung pektin 5.9\% dalam satu gram. Mengingat struktur kompenen pektin banyak mengandung gugus aktif hidroksil dan gugus karboksil, maka pektin juga dapat digunakan sebagai salah satu sumber biosorben. Pektin dan turunan pektin dapat dimanfaatkan sebagai absorben logam berat untuk mengatasi masalah pencemaran lingkungan hidup. Pektin adalah polimer heterosakarida dari asam D-galakturonat yang dihubungkan oleh ikatan 1,4 glikosidik dan banyak terdapat pada lamella tengah dinding tumbuhan. Gugus karboksil pada pektin merupakan gugus fungsi utama yang mampu menyerap logam secara efektif. Pektin dapat berinteraksi dengan logam berat membentuk kompleks nitro lignin- pectin dengan ion tembaga [4]. Modifikasi pektin baik melalui menurunkan derajat esterifikasi pektin, sambung silang (crossling), mencangkok (grifting) dapat meningkatkan daya serap pektin terhadap logam-logam seperti $\mathrm{Cu}(\mathrm{II}), \mathrm{Ni}(\mathrm{II}), \mathrm{Sr}(\mathrm{II}), \mathrm{Pb}$ (II) dan logam lainnya [4].

Arang aktif adalah senyawa karbon yang dihasilkan dari bahan-bahan yang mengandung karbon dengan cara khusus berupa aktivasi dengan menghilangkan hidrogen, air atau senyawa lain dari permukaan karbon sehingga didapatkan permukaan yang lebih luas. Arang atau karbon aktif banyak digunakan dalam dua bentuk yaitu serbuk halus dan granul. Terdapat dua tahap dalam pembuatan karbon aktif, pertama tahap karbonisasi dan kedua tahap aktivasi karbon. Kulit pisang kepok dijadikan arang aktif yang merupakan senyawa karbon yang dihasilkan dari bahan-bahan yang mengandung karbon dengan cara khusus berupa aktivasi dengan menghilangkan hidrogen, air atau senyawa lain dari permukaan karbon sehingga didapatkan permukaan yang lebih luas. Mutu arang aktif diatur dalam SNI 06-3730-1995.

Dalam perairan, logam berat dapat ditemukan dalam bentuk terlarut dan tidak terlarut. Logam berat terlarut adalah logam yang membentuk komplek dengan senyawa organik dan anorganik, sedangkan logam berat yang tidak terlarut merupakan partikel-partikel yang berbentuk koloid dan senyawa kelompok metal yang teradsorbsi pada partikel-partikel yang tersuspensi. Tembaga $(\mathrm{Cu})$ di perairan alami terdapat dalam bentuk partikulat, koloid dan terlarut. Fase terlarut merupakan $\mathrm{Cu}^{2+}$ bebas dan ikatan kompleks, baik dengan ligan inorganik, terutama $\left(\mathrm{CuOH}^{+}, \mathrm{Cu}_{2}(\mathrm{OH})_{2}{ }^{2+}\right)$ maupun organik. Ikatan $\mathrm{Cu}$ kompleks dengan ligan organik, terutama adalah oleh material humus. Tembaga $(\mathrm{Cu})$ termasuk ke dalam kelompok logam essensial, dimana dalam kadar yang rendah dibutuhkan oleh organisme sebagai koenzim dalam proses metabolisme tubuh, sifat racunnya baru muncul dalam kadar yang tinggi. pada konsentrasi 0,01 ppm fitoplankton akan mati karena $\mathrm{Cu}$ menghambat aktivitas enzim dalam pembelahan sel fitoplankton. Konsentrasi $\mathrm{Cu}$ dalam kisaran 2,5-3,0 ppm dalam badan perairan akan membunuh ikan-ikan. 


\section{Metode Penelitian}

\subsection{Alat dan Bahan}

Alat-alat yang digunakan adalah pisau, nampan, mortar, lumpang, tanur, oven, piala gelas $500 \mathrm{ml}$, gelas ukur $100 \mathrm{ml}$, corong, kertas saring, alumunium foil, neraca, perkamen, labu takar $50 \mathrm{ml}$, labu takar $1000 \mathrm{ml}$, pipet volume $25 \mathrm{ml}$, pipet volume $10 \mathrm{ml}$, pipet tetes, bulb, buret $50 \mathrm{ml}$, gelas ukur $100 \mathrm{ml}$, corong kaca, kertas saring, piala gelas $500 \mathrm{ml}$, dan erlenmeyer $250 \mathrm{ml}$.

Bahan baku yang digunakan untuk penelitian adalah kulit pisang, standar logam tembaga (Cu) $1000 \mathrm{ppm}$, asam nitrat $\left(\mathrm{HNO}_{3}\right)$. Natrium hidroksida $(\mathrm{NaOH})$, asam sulfat $\left(\mathrm{H}_{2} \mathrm{SO}_{4}\right)$, potassium iodide, natrium tiosulfat, kanji, benzen, iodin dan potassium dikromat.

\subsection{Prosedur Kerja}

Pembuatan Arang Aktif : Kulit pisang yang telah diperoleh dicuci, dan dipotong dadu. Bahan kulit pisang dikeringkan di bawah sinar matahari sampai benar-benar kering. Kulit pisang yang telah kering dikarbonisasi pada suhu $250{ }^{\circ} \mathrm{C}$ selama 2 jam. Kemudian arang kulit pisang diaktivasi dengan direndam di dalam $\mathrm{HCl} 3 \mathrm{M}$ selama 7 jam. Penggunaan $\mathrm{HCl} 3 \mathrm{M}$ sebagai aktivator mengacu pada [2] sangat efektif untuk mengaktivasi arang. Arang kulit pisang disaring dengan kertas saring kemudian dikeringkan di dalam oven pada suhu $105^{\circ} \mathrm{C}$. Arang dicuci dengan aquadest hingga $\mathrm{pH}$ netral. Kemudian dikeringkan di dalam oven pada suhu $105^{\circ} \mathrm{C}$ dan disimpan dalam wadah bertutup.

Proses Adsorpsi: Arang aktif yang telah dibuat dihaluskan dengan mortar dan alu. Dilewatkan mesh 10, mesh 40, mesh 80, mesh 100, dan mesh 200. Ditampung serbuk arang aktif yang lolos pada setiap ukuran mesh. Disiapkan larutan $\mathrm{Cu} 20$ ppm $100 \mathrm{ml}$ yang sebelumnya telah diatur $\mathrm{pH}$ nya sampai $\mathrm{pH} 3$ dengan penambahan $\mathrm{HNO}_{3} 1 \mathrm{~N}$ atau $\mathrm{NaOH} 1$ N. Digunakan $\mathrm{HNO}_{3}$ dan $\mathrm{NaOH}$ untuk mengontrol $\mathrm{pH}$ larutan karena pereaksi tersebut memiliki ion sejenis dengan baku standar $\mathrm{Cu}$ sehingga tidak mengganggu proses adsorbsi. Suhu larutan $\mathrm{Cu}$ diatur dan dijaga sampai $20^{\circ} \mathrm{C}, 40^{\circ} \mathrm{C}, 60^{\circ} \mathrm{C}, 80^{\circ} \mathrm{C}$ dan $100^{\circ} \mathrm{C}$. Kemudian ditimbang masing-masing mesh arang aktif sebanyak $3 \mathrm{~g}$. serbuk arang aktif yang telah ditimbang dimasukkan masing-masing mesh arang aktif ke dalam masing-masing larutan $\mathrm{Cu}$ yang telah diatur suhunya. Dihomogenkan dan diamkan selama 10 menit. Larutan disaring dengan kertas saring. Filtrat yang didapat dipipet $10 \mathrm{ml}$ larutan, ditambahkan air sampai 100 $\mathrm{ml}, 2 \mathrm{ml}$ asam sulfat pekat dan 3 gram potasium iodide. Titrasi dengan larutan sodium tiosulfat dengan penambahan $1 \mathrm{ml}$ kanji sebagai indikator sampai titik akhir.

\section{Uji Mutu Arang Aktif sesuai SNI 06-3730-1995}

Kadar air: Prosedur penetapan kadar air mengacu pada Standar Nasional Indonesia (SNI) 06-3730-1995 tentang syarat mutu dan pengujian arang aktif. Sebanyak 5 gram contoh yang telah dihaluskan ditimbang dengan teliti dan ditempatkan dalam botol timbang yang telah diketahui bobot kosongnya. Dikeringkan dalam oven pada suhu $105^{\circ} \mathrm{C}$ hingga bobot konstan. Contoh didinginkan dalam eksikator selama 15 menit. Kemudian ditimbang berat akhir bobot botol timbang dan contoh setelah pengeringan. Kadar air dapat dihitung dengan rumus sebagai berikut :[5]

$\operatorname{KadarAir}(\%)=\frac{B-C}{B-A} \times 100 \%$

Kadar Abu Total: Prosedur penetapan kadar abu total mengacu pada Standar Nasional Indonesia (SNI) 06-3730-1995 tentang syarat mutu dan pengujian arang aktif. Ditimbang 1 
gram contoh arang aktif ke dalam cawan porselen yang telah diketahui bobot awalnya. Diarangkan lalu diabukan di dalam tanur pada suhu $600{ }^{\circ} \mathrm{C}$ selama 6 jam. Cawan porselen didinginkan di dalam desikator kemudian ditimbang sebagai bobot akhir. Kadar abu total dapat dihitung dengan rumus sebagai berikut: [5]

$$
\text { KadarAbuTotal }=\frac{C-A}{B-A} \times 100 \%
$$

Daya Serap Terhadap Iod: Prosedur penetapan daya serap terhdapa iod air mengacu pada Standar Nasional Indonesia (SNI) 06-3730-1995 tentang syarat mutu dan pengujian arang aktif. Contoh uji arang aktif ditimbang sebanyak 0.25 gram dan dimasukkan ke dalam Erlenmeyer dan ditambahkan larutan Iod $25 \mathrm{ml}$ diaduk dengan menggunakan stirrer selama 15 menit. Larutan disaring dengan kertas saring, lalu dipipet $10 \mathrm{ml}$ dan dimasukkan ke dalam Erlenmeyer. Dititrasi dengan larutan thio sampai larutan uji berubah warna menjadi tidak berwarna. Daya serap terhadap iod dapat dihitung dengan rumus sebagai berikut: [5]

$$
\text { DayaSeraplod }(\mathrm{mg} / \mathrm{g})=\frac{\left[10-\left(\frac{V s p \times X i}{X t}\right) \times F P \times 126.9\right]}{\text { gramcontoh }}
$$

Daya Serap terhadap Benzene: Prosedur penetapan daya serap terhadap benzena mengacu pada Standar Nasional Indonesia (SNI) 06-3730-1995 tentang syarat mutu dan pengujian arang aktif. Arang aktif ditimbang masing-masing sebanyak 1 gram ke wadah. Lalu dimasukkan ke dalam desikator yang telah dijenuhkan dengan uap benzena dan diamkan selama 24 jam. Kemudian dilakukan penimbangan kembali.[5]

$$
\text { DayaSerapBenzene }(\%)=\frac{B f-A i}{A i} \times 100 \%
$$

Berat Jenis Curah: Prosedur penetapan berat jenis curah mengacu pada Standar Nasional Indonesia (SNI) 06-3730-1995 tentang syarat mutu dan pengujian arang aktif. Arang aktif ditimbang sebanyak 15 gram. Kemudian dimasukkan ke dalam gelas ukur 100 ml. Kemudian dibaca volume arang aktif dalam gelas ukur $100 \mathrm{ml}$. Berat jenis curah dapat dihitung dengan rumus sebagai berikut: [5]

$\operatorname{BeratJenisCurah}(g / m l)=\frac{\operatorname{BobotArang}(g)}{\operatorname{VolumePembacaan}(m l)}$

\section{Rancangan Penelitian:}

Penelitian ini menggunakan Rancangan Acak Kelompok dapat dilihat pada Tabel 1 dengan perlakuan sample sebagai berikut: 
Variabel Ukuran Partikel (A)
A1 $=$ Mesh 10
A2 $=$ Mesh 40
A3 $=$ Mesh 80
A4 $=$ Mesh 100
A5 $=$ Mesh 200
Variabel Suhu (B)
$\mathrm{B} 1=20^{\circ} \mathrm{C}$
$\mathrm{B} 2=40^{\circ} \mathrm{C}$
$\mathrm{B} 3=60^{\circ} \mathrm{C}$
$\mathrm{B} 4=80^{\circ} \mathrm{C}$
$\mathrm{B} 5=100^{\circ} \mathrm{C}$

Tabel 1 Rancangan Penelitian

\begin{tabular}{cccccc}
\hline A/B & A1 & A2 & A3 & A4 & A5 \\
\hline B1 & A1B1 & A2B1 & A3B1 & A4B1 & A5B1 \\
B2 & A1B2 & A2B2 & A3B2 & A4B2 & A5B2 \\
B3 & A1B3 & A2B3 & A3B3 & A4B3 & A5B3 \\
B4 & A1B4 & A2B4 & A3B4 & A4B4 & A5B4 \\
B5 & A1B5 & A2B5 & A3B5 & A4B5 & A5B5 \\
\hline
\end{tabular}

Analisis data hasil pengamatan dilakukan dengan menggunakan uji statistic ANOVA dengan parameter yang dapat dilihat pada Tabel, dengan hipotesis sebagai berikut :

$\mathrm{H} 0=$ Ukuran Partikel dan Suhu tidak berpengaruh pada penyerapan larutan $\mathrm{Cu}$

$\mathrm{H} 1$ = Ukuran Partikel dan Suhu berpengaruh pada penyerapan larutan $\mathrm{Cu}$

Kriteria pengambilan keputusan untuk kriteria yang diuji adalah :

F hitung $<\mathrm{F}$ tabel : terima $\mathrm{HO}$

$\mathrm{F}$ hitung $>\mathrm{F}$ tabel : tolak $\mathrm{H} 0$

Tabel 2 Parameter Uji ANOVA

\begin{tabular}{lllll}
\hline $\begin{array}{l}\text { Sumber } \\
\text { Keragaman }\end{array}$ & dB & $\begin{array}{l}\text { Jumlah } \\
\text { Kuadrat }\end{array}$ & Kuadrat Tengah & F Hitung \\
\hline Perlakuan & $\mathrm{t}-1$ & JKP & KTP $=$ JKP/(t-1) & KTP/KTG \\
Kelompok & $\mathrm{r}-1$ & JKK & KTK $=$ JKK/(r-1) & KTK/KTG \\
Galat & (t-1)(r-1) & JKG & KTG $=$ JKG/t(r-1) & \\
Total & Tr-1 & JKT & & \\
\hline
\end{tabular}

(Sumber: [6])

Dengan rumus-rumus yang digunakan:

1. Faktor Koreksi

$$
F K=\frac{Y_{. .}^{2}}{r t} \text { (6) }
$$

2. Jumlah Kuadrat Total (JKT)

$$
J K T=\sum \sum Y_{i j}^{2}-F K(7)
$$


3. Jumlah Kuadrat Perlakuan (JKP)

$$
J K P=\frac{1}{r} \sum Y_{i}^{2}-F K(8)
$$

4. Jumlah Kuadrat Kelompok (JKK)

$$
J K K=\frac{1}{t} \sum Y_{j}^{2}-F K(9)
$$

5. Jumlah Kuadrat Galat (JKG)

$$
J K G=J K T-J K P-J K K(10)
$$

\section{Hasil dan Pembahasan}

Arang aktif yang telah dibuat, diuji mutu kualitasnya mengacu pada SNI 06-3730-1995 dengan tujuan untuk mengetahui arang yang dibuat telah sesuai dengan kriteria yang ditetapkan. Tabel 3 menunjukkan hasil dari analisa uji mutu arang aktif yang dibandingkan dengan kriteria standar SNI 06-3730-1995. Berdasarkan analisa yang telah dilakukan kadar air yang diperoleh sebesar $8 \%$. Kadar air yang rendah dipengaruhi oleh suhu pemanasan saat pembuatan arang sebesar $250{ }^{\circ} \mathrm{C}$, suhu pengeringan setelah aktivasi $\left(105{ }^{\circ} \mathrm{C}\right)$ serta dipengaruhi oleh cara penyimpanan yang benar. Arang aktif yang telah jadi, disimpan di wadah bertutup yang kedap udara agar uap air tidak masuk, dan menempel pada arang, yang dapat menyebabkan kadar air arang bertambah besar. Kadar abu merupakan sisa dari pembakaran yang sudah tidak memiliki unsur karbon dan nilai kalor lagi[7]. Nilai kadar abu menunjukkan jumlah sisa dari akhir proses pembakaran berupa zat - zat mineral yang tidak hilang selama proses pembakaran[7]. Menurut [8] kadar abu yang tinggi dapat mengurangi daya jerap arang aktif terhadap gas dan larutan, karena mineral seperti kalsium, kalium, magnesium dan natrium menyebar dalam kisi arang aktif dan mempengaruhi pembentukan lebar lapisan kristalit.

Daya serap terhadap larutan akan menentukan kualitas arang aktif sebagai penjerap. Kemampuan arang aktif sebagai penjerap iodin digunakan sebagai parameter kualitas arang aktif bagi tujuan penggunaan[9]. Daya penyerapan arang aktif terhadap iodin memiliki korelasi dengan luas permukaan dari arang aktif. Semakin besar angka iodin maka semakin besar luas permukaan arang aktif dan semakin besar pula kemampuannya dalam menyerap zat terlarut. Mekanisme proses adsorpsi iodin dimulai ketika molekul iodin berdifusi melalui suatu lapisan ke permukaan luar arang aktif dan sebagian larutan iodin berdifusi lanjut ke dalam pori-pori arang aktif. Arang aktif dengan kemampuan menyerap iodin yang tinggi berarti memiliki struktur pori mikro dan mesopori yang banyak [10]. Analisis daya serap arang aktif terhadap iodin dilakukan menggunakan metode titrasi iodometri yaitu dengan larutan iodin sisa adsorpsi oleh arang aktif sebagai titrat dititrasi dengan natrium tiosulfat yang telah distandarisasi sebagai titran dengan reaksi yang terjadi adalah sebagai berikut : [11]

$$
\mathrm{I}_{2}+2 \mathrm{~S}_{2} \mathrm{O}_{3}{ }^{2-} \rightarrow 2 \mathrm{I}^{-}+\mathrm{S}_{4} \mathrm{O}_{6}{ }^{2-}
$$

Berdasarkan Tabel 3 nilai daya serap terhadap iodin arang aktif yang dibuat dari kulit pisang sebesar $2356 \mathrm{mg} / \mathrm{g}$, yang berarti $2356 \mathrm{mg}$ zat terlarut dapat diserap 1 gram arang aktif.

Daya serap terhadap benzen menggambarkan secara umum kemampuan arang aktif untuk menjerap gas. Menurut [12] nilai daya jerap benzen menunjukan kemampuan arang aktif untuk menjerap senyawa yang bersifat non-polar. Artinya, pori-pori pada permukaan arang aktif sedikit mengandung senyawa non-karbon sehingga gas atau uap yang dijerap akan lebih banyak. Sebaliknya rendahnya daya jerap benzen diduga disebabkan oleh masih adanya senyawa yang bersifat polar seperti fenol, aldehida, dan asam karboksilat dari hasil karbonisasi yang tidak sempurna pada permukaan arang aktif. Berat jenis curah adalah suatu besaran kerapatan massa yang dinyatakan dalam berat per satuan volume. Berdasarkan Tabel 
Jurnal Teknologi, Tahun 2019, Volume 6, Edisi 2

2 nilai berat jenis curah arang aktif yang dibuat dari kulit pisang sebesar $0.32 \mathrm{~g} / \mathrm{ml}$. Berdasarkan Tabel 3 tersebut semua parameter uji memenuhi kriteria prasyarat SNI 06-37301995.

Tabel 3 Hasil Uji Mutu Arang Aktif

\begin{tabular}{lcc}
\hline \multicolumn{1}{c}{ Uraian } & Kriteria (SNI) & Hasil \\
\hline Kadar air $(\%)$ & Maks.15 & 8 \\
Kadar abu (\%) & Maks.10 & 7 \\
Daya serap terhadap $\mathrm{I}_{2}(\mathrm{mg} / \mathrm{g})$ & Min.750 & 2356 \\
Daya serap terhadap benzene $(\%)$ & Min. 25 & 51 \\
Berat jenis curah $(\mathrm{g} / \mathrm{ml})$ & $0.3-0.35$ & 0.32 \\
\hline
\end{tabular}

Berikut tabel interaksi pengaruh ukran partikel dan suhu terhadap penyerapan logam $\mathrm{Cu}$ :

Tabel 4 Tabel Interaksi Pengaruh Ukuran Partikel dan Suhu terhadap Penyerapan Logam $\mathrm{Cu}$

\begin{tabular}{ccccccc}
\hline \multirow{2}{*}{$\mathrm{A} / \mathrm{B}$} & \multicolumn{5}{c}{ MESH (A) } \\
\cline { 3 - 7 } & & 10 & 40 & 80 & 100 & 200 \\
\hline $\mathrm{S}$ & 20 & 12.45 & 34.23 & 31.12 & 62.23 & 68.45 \\
$\mathrm{U}$ & 40 & 18.67 & 37.34 & 49.78 & 80.90 & 80.90 \\
$\mathrm{H}$ & 60 & 24.89 & 43.56 & 62.23 & 87.12 & 105.79 \\
$\mathrm{U}$ & 80 & 37.34 & 52.90 & 80.90 & 99.57 & 124.46 \\
$(\mathrm{~B})$ & 100 & 31.12 & 46.67 & 68.45 & 93.35 & 74.68 \\
\hline
\end{tabular}

Berikut grafik interaksi pengaruh ukuran partikel dan suhu terhadap penyerapan $\operatorname{logam} \mathrm{Cu}$ :

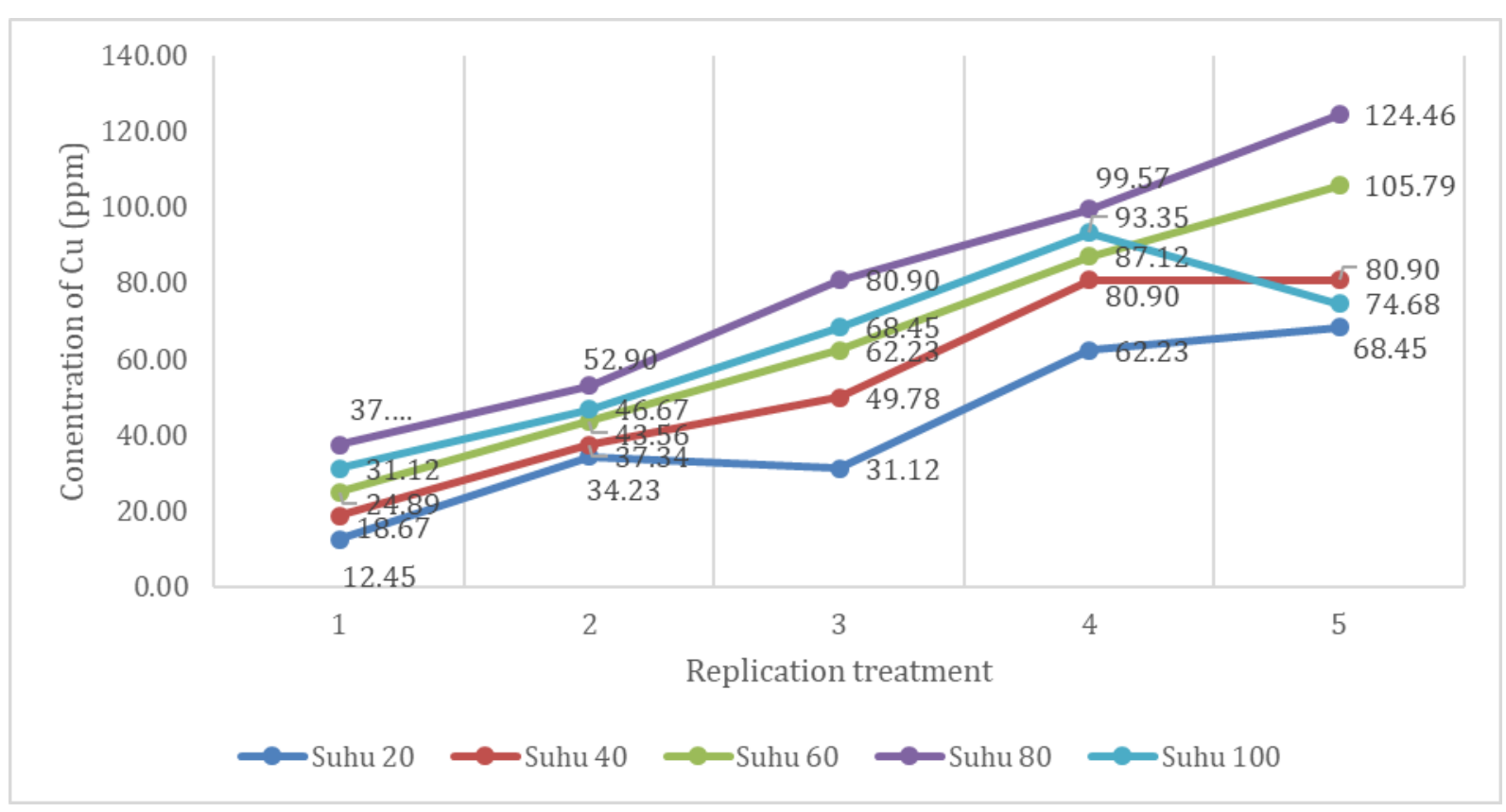

Gambar 1. Interaksi Suhu terhadap Penyerapan Logam Cu dengan Variasi Mesh 


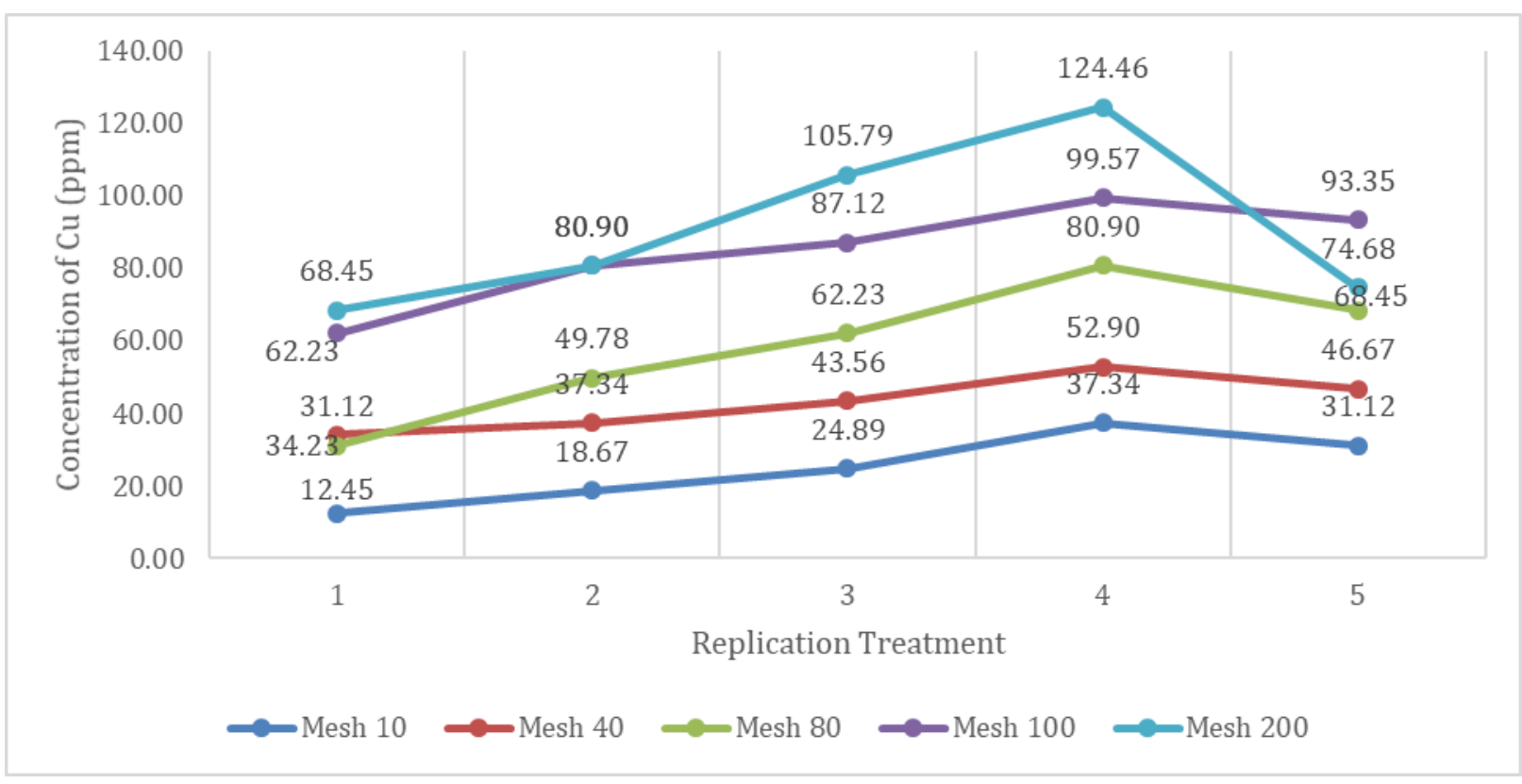

Gambar 2 Interaksi Mesh terhadap Penyerapan Logam dengan Variasi Suhu

Berdasarkan Tabel 4, Gambar 1 dan Gambar 2 interaksi yang telah disajikan diperoleh bahwa semakin tinggi suhu dan semakin kecil ukuran partikel membuat grafik plot line semakin naik, ini menandakan bahwa penyerapan logam $\mathrm{Cu}$ semakin meningkat. Semakin tinggi suhu yang diaplikasikan sebagai suasana untuk penyerapan logam $\mathrm{Cu}$, semakin banyak logam $\mathrm{Cu}$ yang terjerap di arang aktif. Karena proses pemanasan akan menyebabkan pori-pori arang aktif terbuka sehingga daya serapnya meningkat. Namun pemanasan yang berlebihan juga dapat membuat struktur karbon pada arang rusak sehingga daya serapnya menurun. Semakin kecil ukuran partikel, daya penyerapannya akan semakin tinggi karena luas permukaan yang semakin besar [13]. Dengan plot grafik paling besar pada ukuran partikel 200 dan suhu $80^{\circ} \mathrm{C}$.

Arang aktif yang dibuat dari kulit pisang kapok menghasilkan yield $16 \%$. Penelitian ini diterapkan untuk ukuran partikel sampai 200 mesh, yang mana pada grafik yang dihasilkan dengan semua variasi suhu penyerapan logam masih terus naik pada mesh 200. Sehingga belum dapat dikatakan mesh 200 adalah mesh optimum untuk penyerapan logam $\mathrm{Cu}$. Diperlukan penelitian lanjutan untuk mengetahui ukuran partikel optimum penyerapan logam $\mathrm{Cu}$ dengan variasi ukuran partikel dimulai dari $>200$ mesh.

Hipotesis yang dibuat yaitu ukuran partikel dan suhu berpengaruh terhadap penyerapan logam $\mathrm{Cu}$ terbukti berdasarkan data yang telah disajikan tersebut diperkuat dengan analisa uji statistik. Uji statistik digunakan untuk mengeneralisasikan data sampel terhadap populasi. Digunakan uji statistik parametik ANOVA dengan hipotesis H0 dan H1. Statistik parametik merupakan statistik yang digunakan untuk menguji hipotesis yang variabelnya terukur. Pada penelitian ini digunakan dua variabel terukur yaitu suhu $\left(20^{\circ} \mathrm{C}, 40{ }^{\circ} \mathrm{C}, 60{ }^{\circ} \mathrm{C}, 80^{\circ} \mathrm{C}\right.$ dan 100 ${ }^{\circ} \mathrm{C}$ ) dan ukuran partikel (Mesh: 10, 40, 80, 100, dan 200). Dengan hipotesis yang dibuat yaitu:

$\mathrm{HO}=$ Ukuran Partikel dan Suhu tidak berpengaruh pada penyerapan larutan $\mathrm{Cu}$

$\mathrm{H} 1$ = Ukuran Partikel dan Suhu berpengaruh pada penyerapan larutan $\mathrm{Cu}$

Hipotesis nol ( $\mathrm{H} 0)$ adalah hipotesis yang diuji dengan parameter statistik yang biasanya berupa suatu pernyataan tidak adanya perbedaan atau tidak adanya hubungan. Sedangkan hipotesis alternatif (H1) adalah lawan dari H0 yang berupa suatu pernyataan adanya perbedaan atau hubungan. 
Tabel 5 Hasil ANOVA

\begin{tabular}{cccccc}
\hline $\begin{array}{c}\text { Sumber } \\
\text { Keberagaman }\end{array}$ & $\mathrm{db}$ & $\begin{array}{c}\text { Jumlah } \\
\text { kuadrat }\end{array}$ & $\begin{array}{c}\text { Kuadrat } \\
\text { tengah }\end{array}$ & $\begin{array}{c}\mathrm{F} \\
\text { hitung }\end{array}$ & F Tabel \\
\hline Perlakuan & 4 & 3845.46489 & 15381.85956 & 248.25 & 6.388233 \\
Kelompok & 4 & 15420.58529 & 61682.34115 & 995.5 & \\
Galat & 16 & 1239.22 & 61.9611664 & & \\
Total & 24 & 20505.27 & & & \\
\hline
\end{tabular}

\section{Kesimpulan}

Dari hasil penelitian "Pengaruh Ukuran Partikel Dan Suhu Terhadap Penyerapan Logam Tembaga $(\mathrm{Cu})$ dengan Arang Aktif dari Kulit Pisang" dapat disimpulkan bahwa Arang aktif yang dibuat memenuhi kriteria SNI 06-3730-1995. Ukuran partikel interaksi antara ukuran partikel, suhu berpengaruh pada proses penyerapan logam $\mathrm{Cu}$ oleh arang aktif dari kulit pisang. Uji statistik menghasilkan menolak $\mathrm{H} 0$ dan menerima $\mathrm{H} 1$ yaitu ukuran partikel dan suhu berpengaruh pada penyerapan logam $\mathrm{Cu}$.

\section{Daftar Notasi}

A = Bobot wadah kosong (gram)

$\mathrm{B}=$ Bobot wadah +contoh sebelum dikeringkan/diabukan (gram)

$\mathrm{C}=$ Bobot wadah +contoh setelah dikeringkan/diabukan (gram)

$\mathrm{Xt} \quad=$ Konsentrasi larutan penitar $(\mathrm{N})$

Vsp $=$ Volume titrasi contoh $(\mathrm{ml})$

$\mathrm{C} \quad=$ Konsentrasi larutan iodin $(\mathrm{N})$

FP $=$ Faktor Pengenceran

126.9 = Massa relatif iod

$\mathrm{Ai}=$ Bobot arang aktif sebelum mengadsorbsi (gram)

$\mathrm{Bf}=$ Bobot arang aktif setelah mengadsorbsi (gram)

\section{Daftar Pustaka}

[1] M. R. Adinata, "Pemanfaatan Limbah Kulit Pisang Sebagai Karbon Aktif”, Universitas Pembangunan Nasional "Veteran", Jawa Timur, 2013.

[2] Darmayanti., N. Rahman \& Supriadi, “Adsorpsi Timbal (Pb) dan Zink (Zn) dari Larutannya Menggunakan Arang Hayati (Biocharcoal) Kulit Pisang Kepok Berdasarkan Variasi pH”, Jurnal Akademika Kimia. 1(4) : 159 - 165,2012.

[3] F. Jubilate, T. A. Zaharah, I. Syahbanu, "Pengaruh Aktivasi Arang Kulit Pisang Kepok Sebagai Adsorben Besi(II) pada Air Tanah“, JKK. Universitas Tanjung Pura. Pontianak, vol. 5(4), pp. 14-21, 2016

[4] Hastuti Budi, "Pektin dan Modifikasinya untuk Meningkatkan Karakteristik sebagai Absorben", di Seminar Nasional Kimia dan Pendidikan Kimia VIII: Peningkatan Profesionalisme Pendidik dan Periset Sains Kimia di Era Masyarakat Ekonomi ASEAN 
(MEA), Program Studi Pendidikan FKIP UNS, Mei 14, 2016Jawa Tengah: Surakarta, 2016. pp. 157-169

[5] Standar Nasional Indonesia untuk Arang Aktif Teknis, SNI-06-3730-1995, 1995.

[6] R. E. Walpole, Pengantar Statistika Edisi ke-3. Jakarta : PT Gramedia Pustaka Utama. 1995.

[7] N. Fauziah, "Pembuatan Arang Aktif Secara Langsung dari Kulit Acacia mangium Wild dengan Aktivasi Fisika dan Aplikasinya sebagai Adsorben”, Bachelor dissertation, Dept. Chem. Eng. Institur Pertanian Bogor, Bogor, 2009.

[8] Manivannan K, Devi GK, Thiruman, Anantharaman P., "Mineral Composition of Marine Macroalge from Mandapan Coastal Regions; Southest Coast of India", AmeriacanEurasian Journal of Botany 1 (2): 58-67, 2008.

[9] Prawirokusumo S, Utomo T, "Pembuatan Karbon Aktif Hasil Penelitian Lembaga Kimia Nasional", Bandung: Lembaga Ilmu Pengetahuan Indonesia, 1970

[10] Miranti, S.T., " Pembuatan Karbon Aktif dari Bambu dengan Metode Aktivasi Terkontrol Menggunakan Activating Agent H3PO4 dan KOH”, Bachelor dissertation, Dept. Chem. Eng., Universitas Indonesia, Depok, 2012.

[11] Day, R.A dan Underwood, A.L., Analisis Kimia Kuantitas, Jakarta : Erlangga, 2001

[12] Pari G,. "Kajian Struktur Arang Aktif dari Serbuk Gergaji Kayu Sebagai Adsorben Emisi Formaldehida Kayu Lapis”, Ph. D., dissertation, Dept. Chem. Eng. Institur Pertanian Bogor, Bogor, 2004.

[13] Saueprasearsit, P., Nuanjaren, M, Chinlapa, M., "Biosorption of lead (Pb2+) by Luffa cylindrical Fibre”, Environmental Research Journal, 4(1): 157-166, 2010

[14] Andi Arninda, M. Syahrul, M. Zakir, “Adsorbsi Ion Logam Pb(II) dengan Menggunakan Kulit Pisang Kepok (Musa Paradisiaca Linn)”, Universitas Hassanudi : Makassar, 2014.

[15] Suherman, Vanny Maria Agustina Tiwow, Nirmala, "Adsorpsi Ion Tembaga (Cu) dan Ion Besi (Fe) Dengan Menggunakan Arang Hayati (Biocharcoal) Kulit Pisang Raja (Musa sapientum). Universitas Tadulako: Palu, 2015.

[16] Bansal Roop Chand, Meenakshi Goyal, Activated Carbon Adsorption, Taylor and Francis, 2005.

[17] Peter, D. Hoagland, Niccholas Paris, "Chitosan pectin Laminated Films”, J. Agri Food Chemical: 44, 1919 
[18] Mohammad M. Fares, Yahya R.T., Samar T. K, Yousef M, Abdul Haija. "Vascular Shape and Interpenetrating Poly(Acrylic Acid) Grafted Pectin Hydrogels, Biosorption and Desorption Investigations, J.Polym Environ 19: 431-439, 2011.

[19] Khopkar, S. M, “Konsep dasar kimia analitik”, Jakarta: UI-Press, 2003

[20] Palar, H, "Pencemaran dan toksikologi logam berat”, Jakarta: Rineka Cipta, 2008

[21] Lelifajri, "Adsorpsi ion logam Cu (II) menggunakan lignin dari limbah serbuk kayu gergaji," Jurnal Rekayasa Kimia dan Lingkungan, 7(3): 126-129, 2010

[22] Wirawan, T., dan Lestari, S., "Pemanfaatan arang hayati aktif tempurung jarak pagar (jatropha curcas) sebagai adsorben timbal $(\mathrm{Pb})$ dan tembaga $(\mathrm{Cu})$ ", Jurnal Ilmiah Mahakam (7): 59-67, 2008

[23] Atabak, H.R.H., H.G. Tuedeshki., A.Shafaroudi., M.Akbari., J.S. Ghomi \& M.S. Niassar, "Production of Activated Carbon from Cellulose Wastes", Journal of Chemical and Petroleum Engineering, 47(1): 13-25, 2013

[24] Hanum, F., I.M.D., Kaban \& M.A.Tarigan., "Ekstraksi Pektin dari Kulit Buah Pisang Raja (Musa sapientum)”, Jurnal Teknik Kimia. 1(2): 21-26, 2012

[25] Hoong, P.K, "Biosorption of Heavy Metal Ions from Industrial Waste Water by Banana Peel Based Biosorbent”, Dissertation. Iskandar : Universiti Teknologi Petronas, 2013 